Фармацевтична технологія, біофармація, гомеопатія

Pharmaceutical technology, biopharmacy, homeopathy

Рекомендована д. фрармац. наук, профр. Д. І. Дмитрієвським

УДК 615.322:582.739:634.733:547.436].014.21

DOI http://dx.doi.org/10.11603/2312-0967.2017.4.8352

\title{
РОЗРОБКА ОПТИМАЛЬНОГО СКЛАДУ ТА ТЕХНОЛОГІЇ ТАБЛЕТОК ЕКСТРАКТУ ТРАВИ КОЗЛЯТНИКА, ЕКСТРАКТУ ЛИСТЯ ЧОРНИЦІ ТА ТАУРИНУ МЕТОДОМ ПРЯМОГО ПРЕСУВАННЯ
}

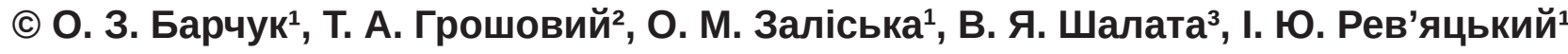 \\ Львівський національний медичний університет імені Данила Галицького ${ }^{1}$ \\ ДВНЗ «Тернопільський державний медичний університет імені І. Я. Горбачевського \\ мОЗ України»² \\ ПАТ «Галичфрарм»³, Львів \\ olvia2003@ukr.net
}

\begin{abstract}
Мета роботи. Вивчення впливу допоміжних речовин на властивості мас для таблетування і основні показники таблеток із метою розробки нового комбінованого таблетованого лікарського засобу з гіпоглікемічною активністю на основі сухих екстрактів із листя чорниці звичайної, трави козлятника лікарського та таурину.

Матеріали і методи. Основні діючі речовини - сухі екстракти з листя чорниці звичайної та трави козлятника лікарського, таурин, допоміжні речовини 6 технологічних груп. Дослідження впливу допоміжних речовин (ДР) на такі показники, як текучість, кут природного укосу, вільну насипну густину, насипну густину після усадки, засипку порошкової маси матриці таблеткової машини і середню масу таблеток після пресування порошкових мас при створенні таблеток екстракту трави козлятника, екстракту листя чорниці та таурину методом прямого пресування проводили відповідно до вимог ДФУ 2 видання.

Результати й обговорення. Вивчено вплив 25-ти ДР на фрармако-технологічні властивості порошкових мас (плинність, кут природного укосу, вільну насипну густину, насипну густину після усадки, процес засипки порошковою масою матриці таблеткової машини) та середню масу таблеток з екстрактом трави козлятника, екстрактом листя чорниці та таурином. За допомогою шестисракторного експерименту - гіпер-греко-латинського квадрату четвертого порядку вивчено вплив 6-ти якісних фракторів на основні показники порошкових мас з екстрактом трави козлятника, екстрактом листя чорниці та таурином. Для кожного із показників побудовані ранжовані ряди переваг вивчених ДР. Результати дисперсійного аналізу експериментальних даних показали, що на текучість порошкових мас екстракту трави козлятника, екстракту трави чорниці і таурину найбільш позитивно впливають тальк, магнію стеарат, МКЦ 112, маніт, МКЦ бурст і натрій карбоксиметилкрохмаль.

Найменше значення кута природного укосу порошкових мас отримували при використанні таблетози, гарке плюс таб., кальцію стеарату, натрій карбоксиметилкрохмалю і кальцію карбонату.

Найбільше значення вільної насипної густини і насипної густини після усадки порошкових мас отримували при використанні таблетози, натрій карбоксиметилкрохмалю, МКЦ+натрій КМЦ, гарке плюс таб., кальцію карбонату, тальку, МКЦ 302, МКЦ 12 і магнію стеарату.

Процес заповнення матриці таблеткової машини порошковою масою екстрактів трави козлятника, листя чорниці і таурину найкраще проходив при використанні натрій карбоксиметилкрохмалю, маніту, кислоти стеаринової, МКЦ 200, магнію карбонату основного.

Найбільше значення середньої маси таблеток екстрактів трави козлятника, листя чорниці і таурину отримували при використанні кальцію карбонату, натрій карбоксиметилкрохмалю, МКЦ 302, МКЦ+натрій КМЦ, магнію стеарату, і маніту.

Отримані результати за показниками текучості порошкових мас, кута природнього укосу, вільної насипної густини до та після ущільнення вказують на можливість отримання таблеток екстракту трави козлятника, екстракту листя чорниці та таурину методом прямого пресування.

Висновки. Вивчено вплив 25-ти ДР на фрармако-технологічні властивості порошкових мас (плинність, кут природного укосу, вільну насипну густину, насипну масу після ущільнення, процес засипки порошковою масою матриці таблеткової машини) та середню масу таблеток з екстрактом трави козлятника, екстрактом листя чорниці та таурином. За допомогою шестифакторного експерименту гіпер-греко-латинського квадрату четвертого порядку вивчено вплив 6-ти якісних фракторів на основні відгуки (показники) порошкових мас з екстрактом трави козлятника, екстрактом листя чорниці та таурином. Побудовані ранжовані ряди переваг впливу ДР на 6 відгуків (показників) порошкових мас і таблеток екстракту трави козлятника, екстракту листя чорниці та таурину.
\end{abstract}

Ключові слова: таблетки; фрармако-технологічні показники порошкових мас і таблеток; рослинні екстракти; чорниця звичайна; козлятник лікарський; таурин; цукровий діабет.

ISSN 2312-0967. Фармацевтичний часопис. 2017. № 4 
Повідомлення 1. Вивчення впливу допоміжних речовин на фрармако-технологічні характеристики порошкових мас при створенні таблеток екстракту трави козлятника, екстракту трави чорниці та таурину методом прямого пресування.

Вступ. Пошук нових та ефективних способів лікування цукрового діабету $є$ однією 3 найважливіших проблем сучасної медицини Згідно з прийнятою резолюцією ООН (від 20 грудня 2006 р., резолюція 61/225) цукровий діабет вважається неінфекційною епідемією [1]. Суттєвою проблемою людства $€$ те, що абсолютна або відносна інсулінова недостатність веде до суттєвих ускладнень (до 50 \% хворих мають діабетичні ускладнення: ретинопатій (66,3 \%), діабетичних полінейропатій (33,4 \%) та нефропатій, що провокує анемії (9,9 \%) [1].

На сьогодні є достатній перелік синтетичних лікарських препаратів, що використовуються для лікування хворих на цукровий діабет. Альтернативою синтетичних засобів $€$ рослини, які можуть служити потенційним джерелом гіпоглікемічних засобів і широко використовуватися в традиційній медицині для профрілактики та лікування ЦД. Протягом останніх років 3 рослин було виділено багато фрітокомпонентів, які проявляли гіпоглікемічний ефект (ферменти, алкалоїди, вітаміни, глікозиди, гормони, ефрірні олії, фрітонциди, мікро- і макроелементи тощо) [2]. За механізмом гіпоглікемічної дії лікарські рослини умовно поділяють на: рослини загальнозміцнювальної дії; лікарські рослини з інсуліноподібними чи гормоноподібними речовинами; лікарські рослини, що мають здатність регулювати обмін речовин [3]. Увагу науковців насамперед привертають рослини, які широко використовуються в народній і практичній медицині для лікування цукрового діабету, що мають достатню сировинну базу [4-6]. Дія препаратів на основі екстрактів козлятника лікарського (галеги лікарської) та чорниці звичайної подібна дії антидіабетичних препаратів групи бігуанідів [7]. Гіпоглікемічний ефект рослин залежить від присутності БАР інсуліноподібної дії : глікозид міртилін, алкалоїд галегін, віт. групи В, макро- і мікроелементів (цинк, хром) амінокислоти (таурин) та полягає у захисті інсуліну від активності фрерментів, нормалізації засвоєння глюкози клітинами, стимуляції синтезу білків та жирів, нормалізуючи порушений вуглеводневий обмін, регенерації $\beta$-клітин острівці Лангерганса [8].

Козлятник (Galega Officinalis L.) та чорниця звичайна (Vaccinium myrtillus L.) проявляють синергічну гіпоглікемічну дію [7]. Враховуючи ефективну гіпоглікемічну дію козлятника лікарського та чорниці звичайної, що базується на їх різноманітному хімічному складі, досвіді використання в терапії цукрового діабету, та недостатній асортимент вітчизняних таблетованих лікарських засобів на їх основі вказує на перспективність подальших досліджень.
Фармацевтична технологія, біофармація, гомеопатія Pharmaceutical technology, biopharmacy, homeopathy

Мета роботи - вивчення впливу ДР на фрармакотехнологічні властивості порошкових мас для таблетування з метою розробки нового комбінованого таблетованого лікарського засобу з гіпоглікемічною активністю на основі сухих екстрактів із листя чорниці звичайної і трави козлятника лікарського та таурину.

Матеріали і методи. При створенні таблеток використовували сухий екстракт трави козлятника лікарського і сухий екстракт листя чорниці звичайної, отримані за технологією, яка наведена в роботах [9,10], а також таурин (серія 090708). При розробці таблеток методом прямого пресування увагу приділяють вибору раціональних допоміжних речовин (ДР) $[11,12]$, згідно 3 Державною Фармакопеєю України (ДФУ) вони повинні забезпечувати виконання певних фрармако-технологічних вимог [13]. У роботі використовували 25 сертифікованих ДР, наданих для дослідження вітчизнянними дистрибюторами «Аврора» і «Вітек» вітчизнянного та зарубіжного виробництва («Орісіл-Калуш» ДП, Ashland Inc, BASF corp,, Blanver Farmoquimica LTDA, Harke Pharma GmbH, JRS Pharma, Fuji Chemical Industri Co, Magnesia $\mathrm{GmbH}$, Mingtai Chemical Co., Ltd Roquette Pharma, Syntapharm, Südzucker).

При стоворенні таблеток чорниці методом прямого пресування вивчали 6 груп ДР, критерієм віднесення яких була належність до певної технологічної класисрікації - наповнювачі на основі цукрів (фактор А), наповнювачі на основі мікрокристалічної целюлози (фактор В), ковзні речовини, які одночасно виконують фрункції регулятора вологи (фактор С), розпушувачі (фрактор D), комбіновані наповнювачі на основі МКЦ (фактор Е) та змащувальні речовини (фрактор F). Всього було вивчено 25 ДР речовин, більшість із яких належить до нових, які з'явилися на фрармацевтичному ринку нещодавно, наукові публікацій щодо їх використання при створенні та виробництві таблеток методом прямого пресування відсутні.

Перелік ДР, які вивчали при створенні таблеток екстракту трави козлятника, екстракту листя чорниці та таурину методом прямого пресування, наведено в таблиці 1.

Доклінічні фрармакологічні дослідження із раціонального співвідношення діючих речовин у складі таблеток виконані на кафедрі фрармакології Тернопільського державного медичного університету імені І. Я. Горбачевського під керівництвом проф. І. М. Кліща $[14,15]$.

При складанні рецептури таблеток співвідношення між діючими та ДР в одній таблетці було наступне (г):

Чорниці екстракт листя 0,280

Козлятника екстракт трава $\quad 0,280$

Таурину $\quad 0,080$

Наповнювачі на основі цукрів (фрактор А), $\quad 0,140$ Наповнювачі на основі МЦК (фактор В) $\quad 0,050$ Ковзні речовини (регулятори вологи) (фрактор C) 0,030 Розпушувачі (срактор D) 0,070 Комбіновані наповнювачі на основі МКЦ (фрактор Е) 0,060 Змащувальні речовини (фрактор F) 0,010

ISSN 2312-0967. Pharmaceutical review. 2017. № 4 
Фармацевтична технологія, біофармація, гомеопатія Pharmaceutical technology, biopharmacy, homeopathy

Таблиця 1. Допоміжні речовини, які вивчалися при розробці складу таблеток, що містять екстракти чорниці та козлятника і таурину методом прямого пресування

\begin{tabular}{|c|c|}
\hline Фактори & Рівні фракторів \\
\hline A - наповнювачі на основі цукрів & $\begin{array}{l}\mathrm{a}_{1}-\text { таблетоза } \\
\mathrm{a}_{2}-\text { лудіпрес } \\
\mathrm{a}_{3}-\text { маніт } \\
\mathrm{a}_{4}-\text { цукор компрі O } \\
\mathrm{a}_{5}-\text { парлітол 100SD+манітол }\end{array}$ \\
\hline $\begin{array}{l}\text { В - ДР різних зразків мікрокристалічної целюлози } \\
\text { (МКЦ) }\end{array}$ & $\begin{array}{l}\mathrm{b}_{1}-\text { МКЦ } 102 \\
\mathrm{~b}_{2}-\text { МКЦ } 12 \\
\mathrm{~b}_{3}-\text { МКЦ } 200 \\
\mathrm{~b}_{4}-\text { МКЦ } 112 \\
\mathrm{~b}_{5}-\text { МКЦ } 302\end{array}$ \\
\hline C - ковзні речовини (регулятори вологи) & $\begin{array}{l}\mathrm{c}_{1}-\text { кальцій карбонат } \\
\mathrm{c}_{2}-\text { неуселін УФЛ } \\
\mathrm{c}_{3}-\text { неуселін УС } 2 \\
\mathrm{c}_{4}-\text { магній карбонат основний } \\
\mathrm{c}_{5}-\text { тальк }\end{array}$ \\
\hline D - розпушувачі & $\begin{array}{l}\mathrm{d}_{1}-\text { кросповідон ХЛ-10 } \\
\mathrm{d}_{2}-\text { натрій кроскармелоза } \\
\mathrm{d}_{3}-\text { натрій крохмальгліколят } \\
\mathrm{d}_{4}-\text { натрій карбоксиметилкрохмаль } \\
\mathrm{d}_{5}-\text { крохмаль преджелетинізований }\end{array}$ \\
\hline $\begin{array}{l}\text { Е - наповнювачі на основі комбінацій похідних } \\
\text { целюлози і МКЦ з іншими ДР }\end{array}$ & $\begin{array}{l}\mathrm{e}_{1}-\text { просолв } 90 \text { (МКЦ+аеросил) } \\
\mathrm{e}_{2}-\text { просолв ОДТ Г } 2 \text { (МКЦ + аеросил + } \\
\text { манітол+срруктоза+кросповідон) } \\
\mathrm{e}_{3}-\text { МКЦ+натрій КМЦ } \\
\mathrm{e}_{4}-\text { МКЦ бурст } \\
\mathrm{e}_{5}-\text { гарке плюс табл. (похідні целюлози+дикальцій фоссрат) }\end{array}$ \\
\hline F - змащувальні речовини & $\begin{array}{l}\mathrm{f}_{1}-\text { магнію стеарат } \\
\mathrm{f}_{2}-\text { кальцію стеарат } \\
\mathrm{f}_{3}-\text { кислота стеаринова } \\
\mathrm{f}_{4}-\text { олія гідрогенізована (лубрітаб) } \\
\mathrm{f}_{5}-\text { натрію стеарилфрумарат }\end{array}$ \\
\hline
\end{tabular}

При вивченні 25 ДР, які згруповані в шість технологічних груп, раціонально в якості плану експерименту використати шестифракторний експеримент на основі гіпер-греко-латинського квадрату [16]. В цьому випадку замість 15625 (5×5×5×5×5×5=15625) серій дослідів, які необхідно реалізувати при традиційному експерименті, коли здійснюється повний перебір всіх можливих комбінацій між рівнями 6 фракторів, реалізовано всього 50 серій дослідів (25 серій в двох повторностях).

Матриця планування експерименту та результати дослідження порошкових мас і таблеток екстракту трави козлятника, екстракту листя чорниці та таурину наведено в таблиці 2.

Кожна серія дослідів була реалізована в двох повторностях. Порошкові маси готували за класичною схемою виробництва багатокомпонентних таблеток, що містять сухі екстракти. Змішували екстракти чорниці листя та козлятника трави. Окремо змішували таурин та ДР чотирьох груп (фактор A, B, D, E) і додавали до суміші сухих екстрактів. Після старанного перемішування додавали ковзні (фрактор С) та зма- щувальні речовини (фактор F). Суміш порошків перемішували та досліджували їі орармако-технологічні влативості - текучість $\left(\mathrm{y}_{1}\right)$, кут природного укосу $\left(\mathrm{y}_{2}\right)$, вільну насипну густину $\left(\mathrm{y}_{3}\right)$ та насипну густину після усадки $\left(\mathrm{y}_{4}\right)$ і засипку матриці таблетної машини $\left(\mathrm{y}_{5}\right)$. Після цього пресували таблетки на лабораторній таблетній машині 3 діаметром 13 мм та масою 1,0 г. Досліджували рівномірність заповнення матриці таблеткової машини порошковою сумішшю діючих та ДР $\left(\mathrm{y}_{6}\right)$.

Матриця планування експерименту на основі гіпер-греко-латинського квадрату четвертого порядку та дослідження порошкових мас і таблеток екстракту трави козлятника, екстракту листя чорниці та таурину наведено в таблиці 2.

Отримані результати підлягали дисперсійному аналізу за схемою шестисракторного експерименту, обчислювальна процедура якого наведена в монографрії [16].

У тих випадках, коли екпериментальне значення F-критерію було більше табличного, робили висновки про статистичну значущість досліджуваного

ISSN 2312-0967. Фармацевтичний часопис. 2017. № 4 
Фармацевтична технологія, біофармація, гомеопатія

Pharmaceutical technology, biopharmacy, homeopathy

\begin{tabular}{|c|c|c|c|c|c|c|c|c|c|c|c|c|c|c|c|c|c|c|c|c|c|c|c|c|c|}
\hline & $>$ & $\begin{array}{l}\mathscr{D} \\
\mathscr{0} \\
\mathscr{g} \\
0\end{array}$ & 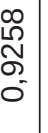 & 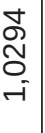 & $\mid \begin{array}{l}-1 \\
\sigma \\
o \\
o \\
0 \\
0\end{array}$ & 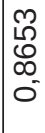 & $\mid \begin{array}{l}\infty \\
\infty \\
\infty \\
\infty \\
0 \\
0\end{array}$ & $\begin{array}{l}0 \\
\infty \\
\infty \\
0 \\
0\end{array}$ & $\left|\begin{array}{l}0 \\
\lambda \\
\hat{\sigma} \\
0 \\
0\end{array}\right|$ & $\begin{array}{l}\mathbb{O} \\
\mathbb{O} \\
\infty \\
0^{-}\end{array}$ & 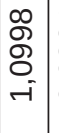 & 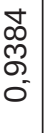 & $\begin{array}{l}8 \\
8 \\
\mathscr{6} \\
\sigma_{0}\end{array}$ & $\left|\begin{array}{l}0 \\
0 \\
0 \\
\mathscr{g} \\
0 \\
0\end{array}\right|$ & $\begin{array}{l}0 \\
\mathscr{D} \\
\bar{g} \\
- \\
\circ\end{array}$ & $\mid \begin{array}{l}\tilde{N} \\
\tilde{S} \\
\sigma \\
\sigma \\
\delta\end{array}$ & 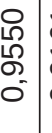 & $\begin{array}{l}-\overrightarrow{0} \\
-1 \\
\sigma \\
\sigma^{\prime}\end{array}$ & & 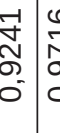 & 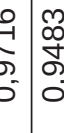 & 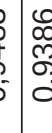 & $\begin{array}{l}\infty \\
-1 \\
0 \\
\infty \\
0\end{array}$ & & $\begin{array}{l}\infty \\
\infty \\
\mathbb{N} \\
0 \\
-1\end{array}$ \\
\hline & & $\mid \begin{array}{l}-1 \\
\tilde{\rho} \\
ٌ \\
\sigma \\
0 \\
0\end{array}$ & 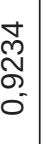 & 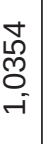 & $\begin{array}{l}\mathscr{8} \\
\mathscr{O} \\
\mathscr{O} \\
0 \\
0\end{array}$ & 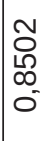 & \begin{tabular}{|l}
0 \\
$\infty$ \\
$o$ \\
$o$ \\
0
\end{tabular} & $\begin{array}{l}\infty \\
\infty \\
\infty \\
0 \\
0 \\
0\end{array}$ & 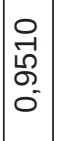 & $\begin{array}{l}\mathscr{8} \\
0 \\
\infty \\
0 \\
0\end{array}$ & $\left|\begin{array}{l}0 \\
0 \\
\infty \\
0 \\
- \\
-1\end{array}\right|$ & 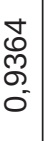 & 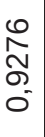 & 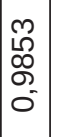 & 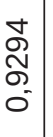 & $\left|\begin{array}{c}0 \\
d \\
a \\
0 \\
0\end{array}\right|$ & $\begin{array}{l}0 \\
0 \\
0 \\
0 \\
0\end{array}$ & $\begin{array}{c}8 \\
8 \\
0 \\
0 \\
0 \\
0^{-}\end{array}$ & 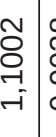 & 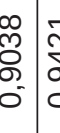 & 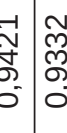 & 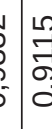 & $\mid \begin{array}{l}\mathscr{O} \\
\tilde{m} \\
\infty \\
0\end{array}$ & & $\begin{array}{l}\tilde{N} \\
\text { O} \\
-i\end{array}$ \\
\hline & $\lambda^{-\infty}$ & $m$ & $m$ & $\nabla$ & 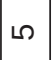 & $\sim$ & $m$ & م & ا & $\nabla$ & $\nabla$ & $m$ & $m$ & $m$ & $m$ & 10 & $\nabla$ & $\nabla$ & ᄂ & كا & $\Omega \quad \nabla$ & 10 & $\checkmark$ & $\nabla$ & L \\
\hline & $\lambda^{\infty}$ & $\nabla$ & $m$ & $\nabla$ & $\nabla$ & $m$ & $m$ & م & م & $\nabla$ & $\nabla$ & $m$ & $m$ & $\nabla$ & $\nabla$ & L) & $\nabla$ & $m$ & + & $\nabla$ & 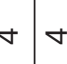 & $r$ & t & $\nabla$ & $\nabla$ \\
\hline & & $\left|\begin{array}{c}\mathbb{N} \\
\infty \\
\infty \\
0 \\
0\end{array}\right|$ & $\begin{array}{l}8 \\
8 \\
0 \\
0\end{array}$ & $\begin{array}{c}0 \\
0 \\
\infty \\
0 \\
0\end{array}$ & $\mid \begin{array}{c}\tilde{N} \\
\infty \\
\infty \\
0^{-}\end{array}$ & $\begin{array}{l}\hat{\tilde{M}} \\
\mathscr{O} \\
0 \\
0\end{array}$ & $\mid \begin{array}{c}0 \\
\stackrel{R}{0} \\
0^{-}\end{array}$ & $\mid \begin{array}{l}\hat{y} \\
0 \\
0\end{array}$ & $\mid \begin{array}{l}\mathbb{M} \\
\infty \\
\infty \\
0 \\
0\end{array}$ & $\begin{array}{c}0 \\
9 \\
0 \\
0 \\
0\end{array}$ & $\begin{array}{c}\mathbb{N} \\
\infty \\
\infty \\
0 \\
0^{-}\end{array}$ & $\begin{array}{c}\text { m } \\
\infty \\
0 \\
0^{-}\end{array}$ & $\begin{array}{l}m \\
\tilde{W} \\
\infty \\
0 \\
0^{-}\end{array}$ & $\mid$\begin{tabular}{|c}
$\mathbb{N}$ \\
$\infty$ \\
$\infty$ \\
0 \\
0
\end{tabular} & $\begin{array}{c}1 \\
\infty \\
\infty \\
0^{-}\end{array}$ & $\mid \begin{array}{c}m \\
m \\
\infty \\
0 \\
0^{-}\end{array}$ & $\begin{array}{c}m \\
m \\
\infty \\
0 \\
0\end{array}$ & $\begin{array}{l}\hat{m} \\
\tilde{\sigma} \\
\sigma^{-}\end{array}$ & 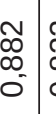 & 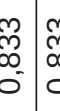 & 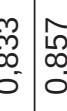 & 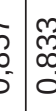 & $\begin{array}{l}8 \\
0 \\
0 \\
0\end{array}$ & & $\begin{array}{l}\mathscr{N} \\
\infty \\
\infty \\
0\end{array}$ \\
\hline 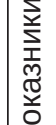 & $\lambda^{+}$ & $\mid \begin{array}{l}\mathscr{8} \\
\dot{Q} \\
0 \\
0\end{array}$ & 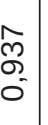 & $\begin{array}{c}0 \\
0 \\
0 \\
0 \\
0 \\
-\end{array}$ & $\begin{array}{l}8 \\
8 \\
0 \\
0\end{array}$ & $\begin{array}{l}\widehat{T} \\
\mathscr{\theta} \\
0 \\
0\end{array}$ & $\mid \begin{array}{l}8 \\
0 \\
0 \\
0\end{array}$ & \begin{tabular}{|l}
$\hat{\mathscr{O}}$ \\
$\mathscr{0}$ \\
0
\end{tabular} & $\mid \begin{array}{l}\hat{L} \\
\infty \\
0 \\
0^{-}\end{array}$ & $\begin{array}{c}\mathbb{M} \\
\infty \\
\infty \\
0 \\
0\end{array}$ & 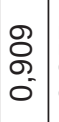 & $\begin{array}{c}\hat{L} \\
\infty \\
0 \\
0\end{array}$ & $\begin{array}{l}\hat{S} \\
\infty \\
0 \\
0\end{array}$ & $\mid \begin{array}{l}\mathscr{8} \\
\dot{\alpha} \\
0 \\
0\end{array}$ & $\begin{array}{c}N \\
\infty \\
\infty \\
0^{-1}\end{array}$ & $\mid \begin{array}{c}\hat{L} \\
\infty \\
0 \\
0\end{array}$ & 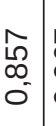 & 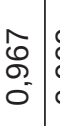 & \begin{tabular}{l|l}
8 \\
$\delta$ \\
0 \\
0
\end{tabular} & 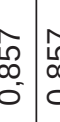 & 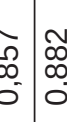 & \begin{tabular}{l|l} 
\\
0 \\
0 \\
0 \\
$b$ & $\infty$ \\
\end{tabular} & 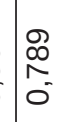 & & $\begin{array}{l}\hat{2} \\
\infty \\
0 \\
0 \\
0\end{array}$ \\
\hline 竞 & 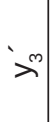 & $\mid \begin{array}{l}\overrightarrow{0} \\
0 \\
0 \\
0\end{array}$ & 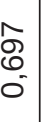 & $\begin{array}{c}\underset{T}{\vec{T}} \\
0^{-}\end{array}$ & $\begin{array}{c}0 \\
\stackrel{h}{\Lambda} \\
0^{-}\end{array}$ & $\mid \begin{array}{l}\mathscr{8} \\
\infty \\
0 \\
0\end{array}$ & $\begin{array}{l}\stackrel{L}{N} \\
0 \\
0^{-}\end{array}$ & $\mid \begin{array}{l}-1 \\
0 \\
0 \\
0 \\
0\end{array}$ & $\begin{array}{l}\overrightarrow{0} \\
0 \\
0 \\
0 \\
0\end{array}$ & 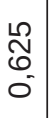 & $\begin{array}{l}\underset{J}{A} \\
\vdots \\
0\end{array}$ & $\begin{array}{l}\hat{8} \\
6 \\
0\end{array}$ & $\begin{array}{l}\vec{A} \\
\vec{N} \\
0^{-}\end{array}$ & $\mid \begin{array}{l}\vec{J} \\
\vec{\lambda} \\
0\end{array}$ & $\begin{array}{l}\hat{8} \\
0 \\
0\end{array}$ & $\left|\begin{array}{l}-1 \\
0 \\
0 \\
0\end{array}\right|$ & $\begin{array}{l}-1 \\
0 \\
0 \\
0 \\
0\end{array}$ & 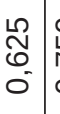 & 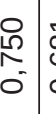 & 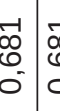 & 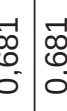 & \begin{tabular}{l|l}
0 \\
0 \\
0 \\
$\vdots$ \\
$\vdots$
\end{tabular} & $\mid \begin{array}{l}\mathbb{N} \\
\mathbb{0} \\
0 \\
0\end{array}$ & & $\begin{array}{l}-1 \\
0 \\
0 \\
0 \\
0\end{array}$ \\
\hline & $>0$ & \begin{tabular}{|l|}
$\hat{8}$ \\
0 \\
0 \\
0
\end{tabular} & $\begin{array}{c}\vec{J} \\
\stackrel{7}{*} \\
0^{-}\end{array}$ & $\begin{array}{l}\vec{m} \\
\stackrel{-}{0} \\
0\end{array}$ & $\begin{array}{l}8 \\
0 \\
0 \\
0 \\
0\end{array}$ & $\begin{array}{l}7 \\
-1 \\
0 \\
0\end{array}$ & $\mid \begin{array}{l}\infty \\
0 \\
0 \\
0 \\
0\end{array}$ & $\begin{array}{l}\hat{i} \\
0 \\
0 \\
0\end{array}$ & $\mid \begin{array}{l}\hat{D} \\
0 \\
0 \\
0\end{array}$ & $\begin{array}{l}\infty \\
0 \\
0 \\
0 \\
0\end{array}$ & $\begin{array}{l}\vec{m} \\
\tilde{N} \\
0\end{array}$ & $\begin{array}{l}\underset{A}{A} \\
0^{-}\end{array}$ & $\begin{array}{c}0 \\
\stackrel{h}{R} \\
0^{-}\end{array}$ & $\left|\begin{array}{l}\vec{p} \\
⿱ \\
0 \\
0\end{array}\right|$ & $\begin{array}{l}\vec{A} \\
\vec{A} \\
0^{-}\end{array}$ & $\begin{array}{l}\hat{8} \\
\dot{0} \\
0\end{array}$ & $\begin{array}{l}\hat{8} \\
0 \\
0\end{array}$ & $\begin{array}{l}\infty \\
m \\
0 \\
0 \\
0\end{array}$ & 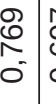 & \begin{tabular}{l|l}
$\hat{b}$ & 0 \\
0 \\
0 \\
0
\end{tabular} & $\begin{array}{ll}\hat{8} & \hat{8} \\
0 \\
0\end{array}$ & $\begin{array}{ll}5 & \\
b \\
b\end{array}$ & 我 & & $\begin{array}{l}\hat{0} \\
0 \\
0 \\
0\end{array}$ \\
\hline & $\lambda^{n}$ & $\left|\begin{array}{c}0 \\
0^{-} \\
-1\end{array}\right|$ & مص & L & $\mid \begin{array}{l}-1 \\
\omega_{-1}\end{array}$ & $\hat{\sim}$ & $\begin{array}{l}0 \\
\infty 0^{-} \\
\sigma^{\prime}\end{array}$ & $\begin{array}{l}10 \\
10 \\
L^{\circ}\end{array}$ & $\begin{array}{l}\hat{A} \\
\vec{A}\end{array}$ & $\hat{0}$ & $\left|\begin{array}{l}-1 \\
0 \\
-1 \\
-1\end{array}\right|$ & $\begin{array}{l}N \\
\tilde{\sigma} \\
\sigma\end{array}$ & $\begin{array}{l}0 \\
\infty^{-} \\
\rightarrow\end{array}$ & $\begin{array}{l}\infty \\
\rightarrow \\
-1\end{array}$ & $\begin{array}{c}N \\
\infty^{-} \\
-1\end{array}$ & $\mid \begin{array}{l}0 \\
\sigma_{-}^{-} \\
\sigma^{2}\end{array}$ & $\begin{array}{l}\infty \\
\underset{-}{-}\end{array}$ & $\stackrel{\rightarrow}{\rightarrow}$ & 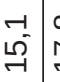 & 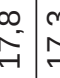 & \begin{tabular}{l|l}
$\stackrel{m}{N}$ & $\infty$ \\
- & 0 \\
-1
\end{tabular} & 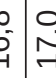 & $\frac{\hat{N}}{\mathrm{H}}$ & & $\stackrel{\stackrel{L}{-}}{\stackrel{-}{-}}$ \\
\hline & $>^{*}$ & $\left|\begin{array}{l}0 \\
n^{-} \\
-1\end{array}\right|$ & 先 & 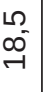 & $\mid \begin{array}{l}10 \\
0 \\
-1\end{array}$ & 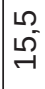 & \begin{tabular}{l}
0 \\
\multirow{-}{*}{} \\
-1
\end{tabular} & $\begin{array}{l}10 \\
0 \\
0 \\
-1\end{array}$ & $\left|\begin{array}{l}\llcorner \\
\infty \\
\infty^{-} \\
\rightarrow\end{array}\right|$ & $\begin{array}{l}\stackrel{10}{2} \\
\stackrel{\rightarrow}{\rightarrow}\end{array}$ & $\begin{array}{l}\vec{\sigma} \\
\vec{\sigma}^{-}\end{array}$ & $\begin{array}{l}\stackrel{0}{2} \\
\stackrel{2}{N}\end{array}$ & $\begin{array}{l}0 \\
\stackrel{-}{-}\end{array}$ & $\left|\begin{array}{l}0 \\
\dot{\sigma} \\
\vec{न}\end{array}\right|$ & 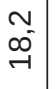 & $\mid$ & 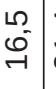 & $\begin{array}{c}+ \\
\text { N }\end{array}$ & \begin{tabular}{l|l}
0 & \\
$\dot{\sigma}^{-}$ &
\end{tabular} & 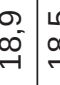 & 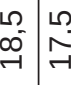 & \begin{tabular}{lll}
0 \\
\hdashline & 0 \\
& 0
\end{tabular} & - & & $\begin{array}{l}\infty \\
\infty^{-} \\
-1\end{array}$ \\
\hline & 5 & $\mid \begin{array}{c}8 \\
\text { m } \\
\text { | }\end{array}$ & $\begin{array}{l}0 \\
0 \\
1 \\
0\end{array}$ & $\begin{array}{l}m \\
m \\
0 \\
\infty \\
i\end{array}$ & $\mid \begin{array}{l}0 \\
\text { m. } \\
\text { న్ }\end{array}$ & $\begin{array}{l}8 \\
8 \\
8\end{array}$ & $\mid \begin{array}{l}2 \\
1 \\
0 \\
0 \\
\infty\end{array}$ & $\begin{array}{l}m \\
m \\
\sigma \\
g\end{array}$ & $\begin{array}{c}0 \\
\stackrel{0}{-} \\
-i \\
\gamma\end{array}$ & 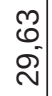 & $\begin{array}{l}\mathscr{E} \\
\emptyset \\
\dot{f}\end{array} \mid$ & $\begin{array}{l}+ \\
\dot{b} \\
\llcorner\end{array}$ & $\begin{array}{l}0 \\
\stackrel{0}{-1} \\
\bar{m}\end{array}$ & $\begin{array}{l}8 \\
8 \\
-1\end{array}$ & \begin{tabular}{c}
0 \\
\multicolumn{1}{c}{} \\
0 \\
-1
\end{tabular} & $\begin{array}{c}m \\
m \\
-1\end{array} \mid$ & 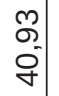 & $\begin{array}{l}0 \\
m \\
\stackrel{N}{N}\end{array}$ & 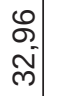 & \begin{tabular}{c|c}
$m$ \\
$m$ \\
$\overbrace{}^{2}$
\end{tabular} & 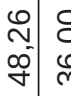 & \begin{tabular}{l|l}
8 & \\
0 & 0 \\
0 & 0
\end{tabular} & $=\frac{8}{8}$ & & $\begin{array}{l}\stackrel{0}{m} \\
\text { N }\end{array}$ \\
\hline & $>$ & $\left|\begin{array}{l}0 \\
\dot{0} \\
\tilde{g} \\
q\end{array}\right|$ & 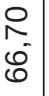 & $\begin{array}{l}0 \\
0 \\
-i \\
0\end{array}$ & $\mid \begin{array}{l}0 \\
\infty \\
\bar{m} \\
-1\end{array}$ & $\begin{array}{l}0 \\
\infty \\
\infty \\
f\end{array}$ & $\begin{array}{l}\infty \\
\infty \\
\infty \\
\infty \\
\infty\end{array}$ & $\begin{array}{l}m \\
m \\
\vec{n} \\
\end{array}$ & $\begin{array}{l}m \\
0 \\
\infty \\
m \\
m\end{array}$ & $\begin{array}{l}m \\
O \\
\mathscr{o}^{-} \\
\sim\end{array}$ & $\mid \begin{array}{l}\stackrel{P}{N} \\
\underset{f}{*}\end{array}$ & $\begin{array}{l}\infty \\
0^{-}\end{array}$ & 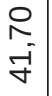 & $\mid \begin{array}{c}\infty \\
\infty \\
\infty \\
\infty \\
-1 \\
-1\end{array}$ & $\begin{array}{l}o \\
+ \\
\sigma_{-}^{-}\end{array}$ & $\left|\begin{array}{l}0 \\
0 \\
0 \\
10 \\
10\end{array}\right|$ & $\begin{array}{l}\infty \\
\infty \\
\mathfrak{Y} \\
\mathcal{F}\end{array}$ & 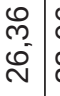 & $\begin{array}{lll}0 & \\
\vdots & \\
m & \end{array}$ & 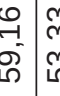 & 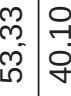 & 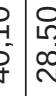 & $\left\{\begin{array}{l}\stackrel{D}{N} \\
\mathbb{f}\end{array}\right.$ & & 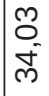 \\
\hline & ५ & + & 4 & 4 & 4 & 14 & |-4 & 4 & $\Psi^{N}$ & $\leftarrow^{m}$ & & $\leftarrow^{+}$ & 4 & $4-1$ & $\leftarrow$ & & 4 & 4 & $-w^{4}$ & 4 & 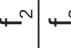 & 4 & $m<+$ & & $4^{-1}$ \\
\hline & ш & $\sigma^{-1}$ & $\oplus^{N}$ & $\oplus^{\infty}$ & $\theta^{\top}$ & $e^{n}$ & $e^{+}$ & $\Phi^{\llcorner}$ & $e^{-1}$ & $\Phi^{N}$ & $e^{\infty}$ & $\mathscr{\Phi}^{N}$ & $\mathscr{e}^{m}$ & $\Theta^{\sigma}$ & $e^{\infty}$ & $\sigma^{-1}$ & $\omega^{\infty}$ & $\Phi^{-1}$ & $\mathscr{\omega}^{N}$ & $\infty^{\infty}$ & $\Phi^{+} \odot$ & $w^{m}$ & $\sigma^{\infty}$ & $\sigma^{-1}$ & $\oplus^{N}$ \\
\hline ธ & | ص & $\sigma^{-1}$ & $\sigma^{N}$ & $\sigma^{\infty}$ & $0^{+}$ & $0^{n}$ & $\delta^{\infty}$ & $\sigma^{+}$ & $\sigma^{20}$ & $\sigma^{-1}$ & $\sigma^{N}$ & $\sigma^{\infty}$ & $\sigma^{-1}$ & $\sigma^{N}$ & $\delta^{m}$ & $\sigma^{+}$ & $\sigma^{N}$ & $\sigma^{m}$ & $\sigma^{+}$ & $\sigma^{20}$ & $\sigma^{-1}$ & $\sigma^{+}$ & $\sigma^{-1}$ & $\sigma^{N}$ & $0^{\infty}$ \\
\hline 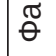 & $u$ & 0 & $u^{\sim}$ & $0^{\infty}$ & $0^{\dagger}$ & $0^{n}$ & $u^{N}$ & $0^{\infty}$ & $0^{+}$ & $0^{\infty}$ & $0^{-1}$ & $u^{m}$ & $u^{+}$ & $0^{n}$ & $\overrightarrow{0}$ & $0^{N}$ & $0^{\top}$ & $u^{n}$ & 0 & $0^{N}$ & $u^{m}$ & u & $0^{2}$ & $0^{\infty}$ & $0^{\sigma}$ \\
\hline & $\infty$ & $0^{-1}$. & مـ & $\varrho^{\infty}$ & $0^{+}$ & مी & مـ & $\Omega^{\infty}$ & $0^{m}$ & $0^{+}$ & مـ & $0^{-1}$ & $\Omega^{N}$ & $0^{\infty}$ & م & $0^{n}$ & $0^{-1}$ & $\overbrace{}^{\curvearrowright}$ & هُ & $0^{+}$ & م' & $0^{-1}$ & $0^{m}$ & $0^{+}$ & $0^{\ln }$ \\
\hline & $\varangle$ & $\sigma^{-1}$ & $\sigma^{-1}$ & $\sigma^{-1}$ & $\sigma^{-1}$ & $\sigma^{\top}$ & $\pi^{N}$ & $\pi^{\infty}$ & $\pi^{2}$ & $\sigma^{N}$ & $\pi^{N}$ & $\sigma^{m}$ & $\sigma^{m}$ & $\sigma^{\infty}$ & $\sigma^{m}$ & $\pi^{\infty}$ & $\sigma^{\top}$ & $\sigma^{+}$ & $\sigma^{+}$ & $\sigma^{+} \Omega$ & $\sigma^{+} \pi$ & $\sigma^{\infty}$ & $\pi^{20}$ & $\sigma^{\infty}$ & $\pi^{\infty}$ \\
\hline & & -1 & $N$ & m & 穴 & L & 0 & & $\infty$ & $\sigma$ & 위 & $\exists$ & & $\stackrel{m}{\rightarrow}$ & & - & $\stackrel{\bullet}{\rightarrow}$ & ને & & g) & 으 & $\vec{v}$ & $\stackrel{N}{\sim}$ & & $\tilde{N}$ \\
\hline
\end{tabular}

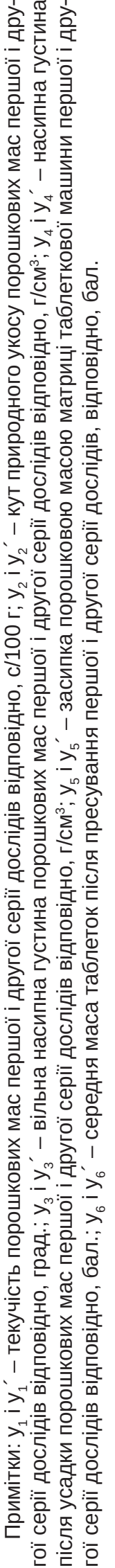


Фармацевтична технологія, біофармація, гомеопатія Pharmaceutical technology, biopharmacy, homeopathy

фрактора, будували рисунки та здійснювали обговорення отриманих результатів. У випадку, коли F-критерій був менше табличного, приймали до уваги, що між рівнями незначущого фрактора немає різниці на досліджуваний відгук (показник). Це означає, що будь-яка ДР із вивченою групи дає однаковий результат на досліджуваний відгук.

Результати й обговорення. Результати дисперсійного аналізу показали, що на текучість порошкових мас екстракту трави козлятника, екстракту листя чорниці та таурину впливають вивчені фрактори в наступній послідовності: C > F > B > A > E > D.

Вплив ковзних речовин на текучість порошкових мас екстракту трави козлятника, екстракту трави чорниці і таурину наведено на рисунку 1.

3 даних рисунка 1 видно, що найкращу текучість має порошкова суміш, що містить у своєму складі тальк (31,40 c/100), який має перевагу над кальцію карбонатом (33,38 c/100 г), магнію карбонатом основним (37,22 c/100 г) і суттєву перевагу над неуселіном УС $2(57,21 \mathrm{c} / 100$ г) та неуселіном УФЛ (65,79 c/100 г).

Подібним чином, за допомогою побудованих рисунків, розглядали вплив інших груп ДР на фрармако-технологічні властивості порошкових мас екстракту трави козлятника, екстракту листя чорниці та таурину.

Серед вивчених змащувальних речовин найкращу текучість порошкових мас екстракту трави козлятника, екстракту листя чорниці та таурину забезпечує магнію стеарат (40,89 c/100 г), який має перевагу над кальцію стеаратом (42,76 c/100 г), кислотою стеариновою (43,51 c/100 г), олією гідрогенізованою (43,90 c/100 г) і натрію стеарилфумаратом (53,92 c/100 г).
Серед вивчених зразків МКЦ найкращу текучість порошкових мас екстракту трави козлятника, екстракту листя чорниці та таурину проявляє МКЦ 112 $(40,59$ c/100 г), яка має перевагу над МКЦ 12 (42, c/100 г) МКЦ 200 (42,56 c/100 г) та суттєву перевагу над МКЦ 102 (46,90 c/100 г та МКЦ 302 (52, c/100 г).

Вплив наповнювачів на основі цукрів на текучість порошкових мас екстрактів чорниці, козлятника і таурину можна зобразити наступним рядом переваг: маніт $(39,35$ c/100 г) > цукор компрі О (42,05 c/100 г) > парлітол+манітол $(44,03$ c/100 г) > лудіпрес $(48,72$ c/100 г) > таблетоза (49,49 c/100 г).

Найкращу текучість порошкових мас екстрактів чорниці, козлятника і таурину серед вивчених модифрікацій МКЦ проявляє МКЦ бурст (42,01 c/100 г), яка має перевагу над просолвом ОДТ Р 2 (43,76 c/100 г), гарке плюс табл. (44,03 c/100 г), просолвом 90 (46,31 с/100 г) та МКЦ+натрій КМЦ (48,27 с/100 г).

Ранжований ряд переваг впливу розпушувачів на текучість порошкових мас екстрактів чорниці, козлятника і таурину має такий вигляд: натрій карбоксиметилкрохмаль (42,32 с/100 г) > натрій крохмальгліколят (43,93 c/100 г) > кросповідон ХЛ 10 (44,84 c/100 г) $>$ крохмаль преджелетитнізований $(46,65$ c/100 г) > натрій кроскармелаза (47,24 c/100 г).

Кут природного укосу характеризує здатність порошкових мас до отримання таблеток методом прямого пресування. Чим менше значення кута природного укосу, тим більша здатність порошкових мас до прямого пресування. Критичним показником вважається $42^{\circ}$. Первинні результати 3 визначення кута природного укосу показують добрі показники, що дає

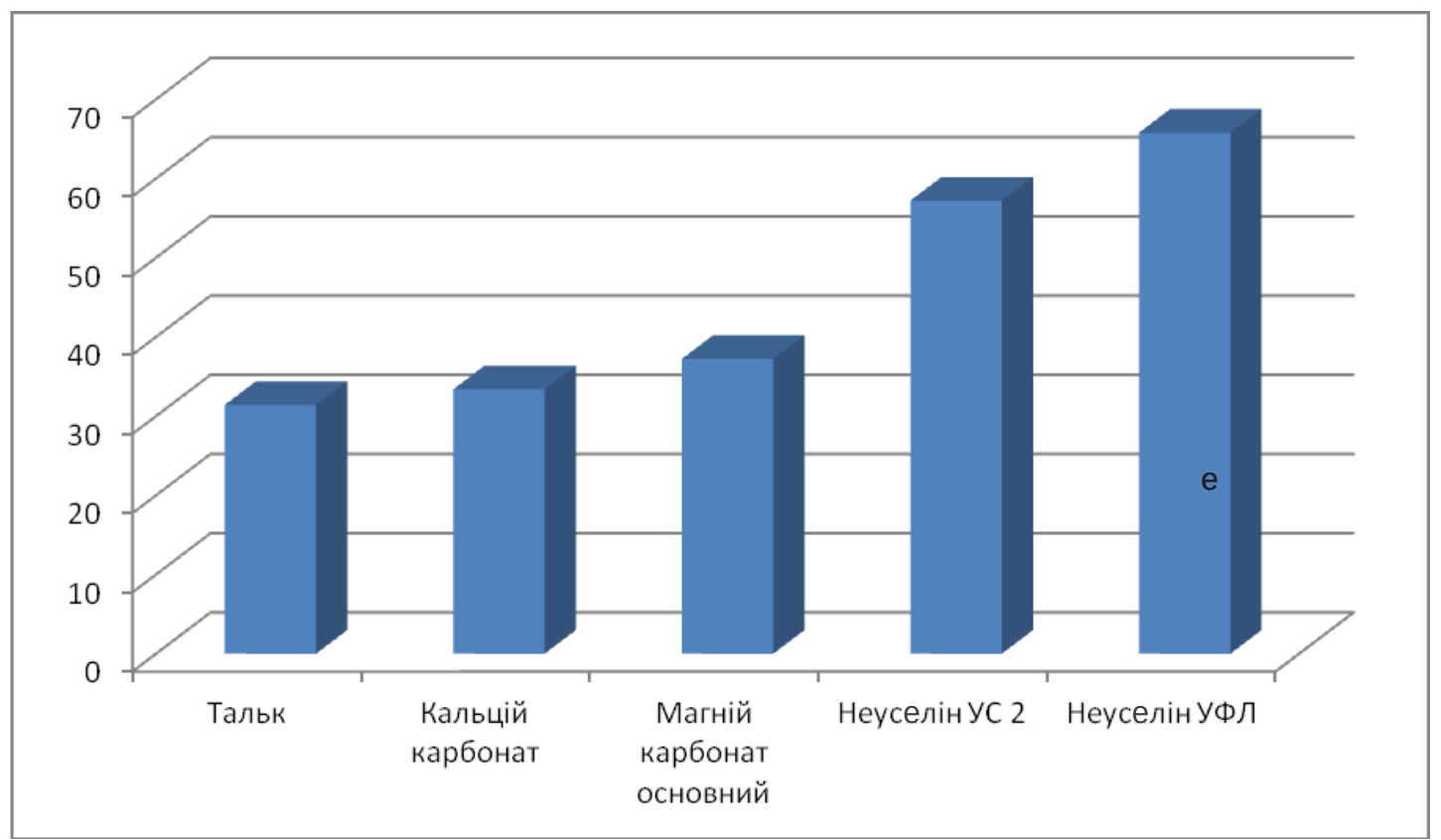

Рис. 1. Вплив допоміжних речовин із високою поверхнею на текучість порошкових мас екстрактів чорниці листя, козлятника трави та таурину.

ISSN 2312-0967. Фармацевтичний часопис. 2017. № 4 
надію на отримання таблеток екстракту трави козлятника, екстракту листя чорниці та таурину чорниці методом прямого пресування.

Вплив вивчених фракторів на кут природного укосу таблетованої маси екстракту трави козлятника, екстракту листя чорниці та таурину має наступний вигляд: A > E > D > C > B при статистичній незначущості фрактора $\mathrm{F}$.

Найменше значення кута природного укосу таблетованої маси з екстрактом трави козлятника, екстрактом листя чорниці і таурином спостерігається при використанні таблетози $\left(15,9^{\circ}\right)$, яка має переваги над цукром компрі О $\left(17,6^{\circ}\right)$, лудіпресом $\left(18,1^{\circ}\right)$, парлітолом+манітолом $\left(18,1^{\circ}\right)$ та манітом $\left(19,1^{\circ}\right)$.

Найкраще значення кута природного укосу таблетованої маси серед вивчених модифікацій МКЦ спостерігається при використанні гарке плюс таб. $\left(16,7^{\circ}\right)$. Наступні місця займають МКЦ бурст $\left(17,4^{\circ}\right)$, просолв ОДТ Г 2 (17,8), МКЦ+натрій КМЦ $\left(18,3^{\circ}\right)$ і просолв 90 $\left(18,6^{\circ}\right)$.

Найменше значення кута природного укосу порошкових мас при вивченні змащувальних речовин спостерігається при використанні кальцію стеарату $\left(17,2^{\circ}\right)$, магнію стеарату $\left(17,3^{\circ}\right)$ і натрію стеарилфумарату $\left(17,4^{\circ}\right)$.

Вказані ДР мають перевагу над кислотою стеариновою $\left(18,2^{\circ}\right)$ та олією гідрогенізованою $\left(18,6^{\circ}\right)$.

Ранжований ряд переваг впливу розпушувачів на кут природного укосу порошкових мас екстракту трави козлятника, екстракту листя чорниці та таурину має наступний вигляд: натрій карбоксиметилкрохмаль $\left(16,9^{\circ}\right)>$ натрій кроскармелоза $\left(17,4^{\circ}\right)>$ крохмаль преджелетинізований $\left(17,8^{\circ}\right)>$ кросповідон ХЛ $10\left(18,2^{\circ}\right)>$ натрій крохмалгліколят $\left(18,4^{\circ}\right)$.

Найменше значення кута природного укосу порошкових мас екстракту трави козлятника, екстракту листя чорниці та таурину серед вивчених ковзних речовин спостерігається при використанні кальцію карбонату $\left(17,2^{\circ}\right)$. Наступні місця в ряду переваг займають магнію карбонат основний $\left(17,4^{\circ}\right)$, неуселін УФЛ $\left(17,8^{\circ}\right)$, неуселін УС $2\left(18,2^{\circ}\right)$ та тальк $\left(18,2^{\circ}\right)$.

Здатність таблетованих порошкових мас до прямого пресування характеризує вільна насипна густина та насипна густина після усадки. При цьому, чим більше значення вільної та насипної густини після усадки, тим більша ймовірність отримати таблетки методом прямого пресування.

Вплив вивчених ДР на вільну насипну густину екстрату трави козлятника, екстракту листя чорниці та таурину має наступний вигляд: $A>B>C>F>D>E$, а після усадки $-\mathrm{A}>\mathrm{B}>\mathrm{C}>\mathrm{F}=\mathrm{D}>\mathrm{E}$.

Найбільше значення вільної насипної густини компонентів таблеток з екстрактом трави козлятника, екстрактом листя чорниці і таурином при дослідженні наповнювачів на основі цукрів спостерігається при використанні таблетози $(0,735$ г/см³). Вказана ДР має переваги над манітом $(0,711$ г/см³), цукром компрі О
Фармацевтична технологія, біофармація, гомеопатія

Pharmaceutical technology, biopharmacy, homeopathy

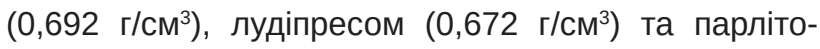
лом+манітолом $(0,662$ г/см³).

При дослідженні насипної густини після маси після усадки компонентів найбільше значення теж спостерігається при використанні таблетози (0,897 г/см³). Цукор компрі $\mathrm{O}$, на відміну від вільної насипної густи-

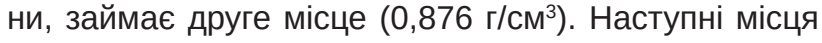

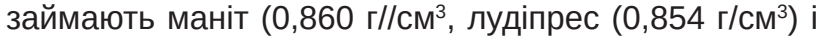

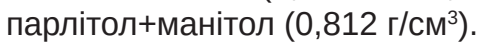

Ранжований ряд переваг впливу розпушувачів на вільну насипну густину екстракту трави козлятника, екстракту листя чорниці та таурину має наступний вигляд: натрій карбоксиметилкрохмаль $(0,717$ г/см³) > крохмаль преджелетенізований $(0,714$ г/см³) > натрій кроскармелоза $(0,690$ г/см³) > натрій крохмальгліколят

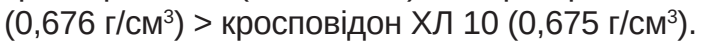

Ряд переваг для вільної насипної густини та насипної густини порошкових мас після усадки однаковий, збільшується тільки середнє значення насипної густини після усадки. Ранжований ряд переваг розпушувачів за впливом на вільну насипну густину порошкових мас після усадки має наступний вигляд: натрій карбоксиметилкрохмаль $(0,891$ г/см³) > крох-

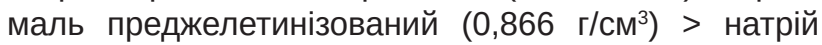
кроскармелоза $(0,858$ г/см³ $)>$ натрій крохмальгліко-

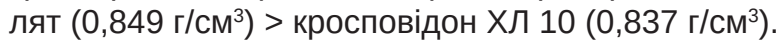

Найбільше значення вільної насипної густини отримали при використанні в якості ДР МКЦ+натрій КМЦ $(0,711$ г/см³). Наступні місця займають гарке

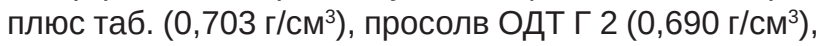

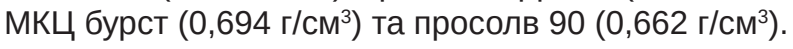

Після дослідження порошкових мас на насипну густину після усадки ефективність вивчених ДР є іншою порівняно з вільною насипною густиною. Так, на першому місці знаходиться наповнювач гарке плюс таб. $(0,879$ г/см³ $)$, наступні місця займають просолв

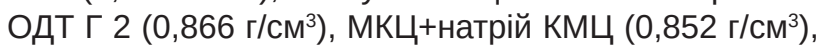

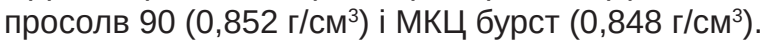

Найбільше значення вільної насипної густини отримано при використанні кальцію карбонату $(0,723$ г/см³). Наступні місця займають магнію карбо-

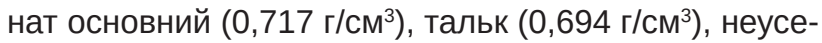

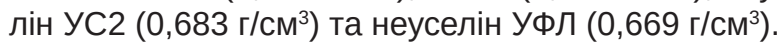

Після дослідження порошкових мас на насипну густину після усадки найбільше значення отримали при використанні тальку $(0,898$ г/см³). Для інших вивчених ДР отримано однакову послідовність, як при дослідженні вільної насипної густини: кальцій карбонат $(0,880$ г/см³)

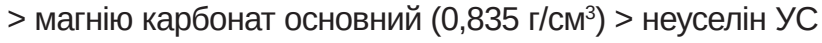

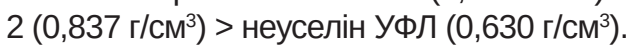

Найбільше значення вільної насипної густини порошкової маси компонентів таблеток отримали при використанні МКЦ $302(0,718$ г/см³), яка має перевагу

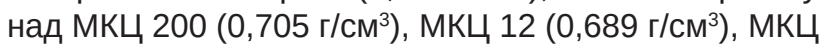

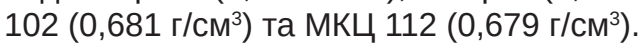

Після дослідження порошкових мас після усадки ряд переваг для вивчених зразків ДР має наступний

ISSN 2312-0967. Pharmaceutical review. 2017. № 4 
Фармацевтична технологія, біофармація, гомеопатія Pharmaceutical technology, biopharmacy, homeopathy

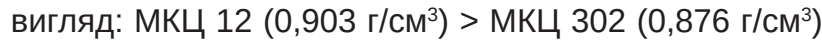

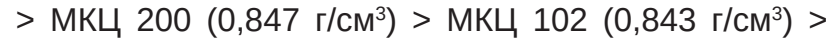

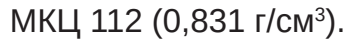

Найбільше значення вільної насипної густини компонентів таблеток екстракту трави козлятника, екстракту листя чорниці та таурину спостерігається при використанні натрій стеарилфумарату

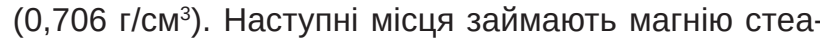

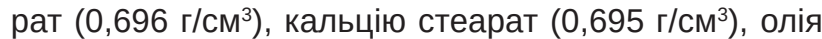
гідрогенізована $(0,690$ г/см³ $)$ та кислота стеаринова $\left(0,684 \mathrm{r} / \mathrm{cm}^{3}\right)$.

Після дослідження порошкових мас на насипну густину після усадки перше місце займає магнію стеарат $(0,886$ г/см³ $)$, а натрій стеарилорумарат - остан-

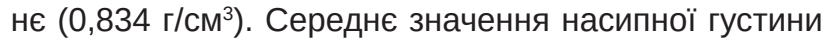
після усадки для олії гідрогенізованої складало

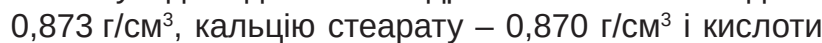

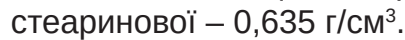

Отримані результати за показником текучості порошкових мас, кута природного укосу, вільної насипної густини та насипної густини після усадки вказують на можливість отримання таблеток екстракту трави козлятника, екстракту листя чорниці та таурину методом прямого пресування.

У процесі пресування таблеток важливим чинником $€$ заповнення таблетковою масою матриці таблеткової машини, особливо при використанні методу прямого пресування. В автоматичному режимі роботи таблеткової машини засипка порошкової маси в матрицю може бути різною. При пресуванні таблеток екстракту трави козлятника, екстракту листя чорниці та таурину здійснювали оцінку процесу засипки матриці порошковою масою за 5-бальною шкалою. При повній засипці матриці експерти виставляли оцінку 5 балів. При неповній засипці, коли незначна частина простору матриці залишалася вільною, виставляли оцінку 4 бали. При більш суттєвому порушенні процесу заповнення матриці експерти виставляли оцінку 3 бали.

Вплив вивчених фракторів на процес заповнення матриці таблеткової машини порошкової маси з екстрактом трави козлятника, екстрактом листя чорниці та таурину має наступний вигляд: $\mathrm{D}>\mathrm{A}>\mathrm{F}>\mathrm{B}>\mathrm{C}$.

Ранжований ряд переваг впливу розпушувачів на процес заповнення матриці таблеткової машини має наступний вигляд: натрій карбоксиметилкрохмаль (4,6 бала) > крохмаль преджелетинізований (3,9 бала) > кросповідон ХЛ 10 (3,8 бала) > натрій кроскармелоза (3,7 бала) > натрій крохмальгліколят (3,7 бала).

Найкраще заповнення матриці таблеткової машини спостерігається при використанні маніту (4,2 бала), цукру компрі О (4,2 бала) і парлітолу+манітолу (4,2 бала). Вказані ДР мають перевагу над лудіпресом (3,6 бала) та таблетозою (3,5 бала).

Найкраще заповнення матриці порошковою масою з екстрактом трави козлятника, екстрактом лис- тя чорниці та таурином спостерігається при вмісті в її складі кислоти стеаринової (4,3 бала). Наступні місця займають магнію стеарат (4,2 бала), кальцію стеарат (4,0 бала), олія гідрогенізована (3,8 бала) та натрій стеарилфумарат (3,4 бала).

Серед вивчених зразків МКЦ найкраще заповнення матриці таблеткової машини порошковою масою відбувається при використанні МКЦ 200 (4,2 бала). Наступні місця за вказаним показником займають МКЦ 112 (4,1 бала), МКЦ 302 (4,1 бала) МКЦ 12 (3, бала) та МКЦ 102 (3,5 бала).

Найкраще заповнення матриці таблеткової машини спостерігається при використанні магнію карбонату основного (4,2 бала), який має перевагу над неуселіном УС2 (4,1 бала), кальція карбонатом (4,0 бала), неуселіном УФЛ (3,9 бала) та тальком (3,5 бала).

Ще одним показником, який характеризує процес заповнення матриці таблеткової машини, можна виразити через середню масу зпресованих таблеток екстракту трави козлятника, екстракту листя чорниці та таурину. При цьому чим більше значення середньої маси таблеток, тим більше стає придатною таблетована маса для прямого пресування.

Вплив вивчених фракторів на значення середньої маси таблеток екстракту трави козлятника, екстракту листя чорниці та таурину можна зобразити наступним рядом: $\mathrm{C}>\mathrm{B}>\mathrm{D}>\mathrm{E}>\mathrm{F}>\mathrm{A}$.

Найбільше значення середньої маси таблеток екстракту трави козлятника, екстракту листя чорниці та таурину отримували при використанні кальцію карбонату (0,9935 г), який має перевагу над магнію карбонатом основним (0,9723 г), неуселіном УС 2 (0,9613 г), тальком $(0,9079)$ і неуселіном УФЛ (0,8978 г).

Ранжований ряд переваг для вивчених розпушувачів на середню масу таблеток екстракту трави козлятника, екстракту листя чорниці та таурину має наступний вигляд: натрій карбоксиметилкрохмаль $(0,9933$ г) > натрій кроскармелоза $(0,9627$ г) > натрій крохмальгліколят $(0,9424$ г) > крохмаль преджелетинізовай (0,9191 г) > кросповідон ХЛ 10 (0,9155 г).

Серед вивчених зразків МКЦ найбільше значення середньої маси таблеток екстракту трави козлятника, екстракту листя чорниці та таурину спостерігаєть при використанні МКЦ 302 (0,9832 г), яка має переваги над МКЦ 200 (0,9752 г), МКЦ 12 (0,9379 г), МКЦ 1121 (0,9200 г) і МКЦ 102 (0,9166 г).

Найбільше значення середньої маси таблеток екстракту трави козлятника, екстракту листя чорниці та таурину отримали при використанні суміші МКЦ+ натрій КМЦ (0,9856 г), яка має переваги над просолвом ОДТ Г 2 (0,9614 г), просолвом 90 (0,9395 г), МКЦ бурст (0,9341 г) і гарке плюс таб. (0,9122 г).

Найбільше значення середньої маси таблеток екстракту трави козлятника, екстракту листя чорниці та таурину отримали при використанні магнію стеарату (0,9722 г), який має перевагу над олією гідрогеніза-

ISSN 2312-0967. Фармацевтичний часопис. 2017. № 4 
том (0,9561 г), кислотою стеариновою (0,9468 г), кальцію стеаратом (0,9436 г) та натрію стеарилфумаратом (0,9142 г).

Найбільше значення середньої маси таблеток екстракту трави козлятника, екстракту листя чорниці та таурину отримували при використанні маніту (0,9572 г), таблетози (0,9551 г) і цукру компрі О (0,9521 г). Вказані ДР мають перевагу над лудіпресом $(0,9445$ г) і парлітолом+манітолом (0,9266 г).

Проведені дослідження показали, що при пресуванні таблеток екстракту трави козлятника, екстракту листя чорниці та таурину засипка матриці таблеткової машини порошковою масою була різною. Побудовані ряди переваг дозволи виділити «лідерів» серед вивчених ДР на вказаний показник. В тих серіях дослідів, де була погана засипка, отримували значення середньої маси таблеток екстракту трави козлятника, екстракту листя чорниці та таурину менше від розрахункового. Тільки в 6 серіях дослідів із 25 засипка матриці таблеткової машини і значення середньої маси спресованих таблеток екстракту трави
Фармацевтична технологія, біофармація, гомеопатія Pharmaceutical technology, biopharmacy, homeopathy козлятника, екстракту листя чорниці та таурину були добрими. Отже, при раціональному поєднанні кращих ДР можна отримати таблетки екстракту трави козлятника, екстракту листя чорниці та таурину методом прямого пресування.

Висновки. 1. Вивчено вплив 25-ти допоміжних речовин на фрармако-технологічні властивості порошкових мас (плинність, кут природного укосу, вільну насипну густину, насипну масу після ущільнення, процес засипки порошковою масою матриці таблеткової машини, середню масу таблеток) з екстрактом трави козлятника, екстрактом листя чорниці та таурином.

2. За допомогою шестифакторного експерименту гіпер-греко-латинського квадрату четвертого порядку вивчено вплив 6-ти якісних фракторів на основні відгуки (показники) порошкових мас з екстрактом трави козлятника, екстрактом листя чорниці та таурином.

3. Побудовані ранжовані ряди переваг впливу допоміжних речовин на 6 відгуків (показників) порошкових мас і таблеток екстракту трави козлятника, екстракту листя чорниці та таурину.

\title{
РАЗРАБОТКА ОПТИМАЛЬНОГО СОСТАВА И ТЕХНОЛОГИИ ТАБЛЕТОК ЭКСТРАКТА ТРАВЫ КОЗЛЯТНИКА, ЭКСТРАКТА ЛИСТЬЯ ЧЕРНИКИ И ТАУРИНА МЕТОДОМ ПРЯМОГО ПРЕССОВАНИЯ
}

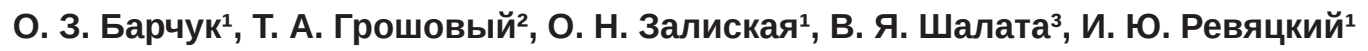 \\ Львовский национальный медицинский университет имени Данила Галицкого \\ ГВУЗ «Тернопольский государственный медицинский университет имени И. Я. Горбачевского \\ МЗ Украины»² \\ ПАТ «Галичфрарм»³, Львов \\ olvia2003@ukr.net
}

Цель работы. Изучение влияния вспомогательных веществ на фрармако-технологические свойства таблетируемых масс з целью разработки нового комбинированого таблетированного лекарственного средства с гипогликемической активностью на основании сухих экстрактов листья черники и травы козлятника и таурина.

Материалы и методы. Основные действующие вещества - сухие экстракты листья черники обыкновенной, козлятника лекарственного и таурина, вспомогательные вещества 6 технологических груп. Иследование влияния вспомогательных вещества (BВ) на фрармако-технологические показатели таблетируемых масс и таблеток при разработке таблеток экстракта листья черники, экстракта козлятника и таурина проводили соотвецтвенно ГФУ 2 выпуска.

Результаты и обсуждение. Изучено влияние 25-ти пяти ВВ на фрармако-технологические свойства таблетируемых масс на среднюю массу таблеток с экстрактом травы козлятника, экстрактом листья черники и таурина. С помощью шестифакторного эксперимента - гипер-греко-латинского квадрата четвертого уровня изучено влияние 6-ти качественных фракторов на основные показатели таблетируемых масс с экстрактом травы козлятника, экстрактом листья черники и таурина. Для каждого из показателей построены ранжированные ряды преимуществ ВВ.

Результаты дисперсионного анализа экперементальных даных показали, что на текучесть таблетируемых масс экстракта травы козлятника, экстракта листья черники и таурина наиболее позитивно влияют тальк, магния стеарат, МКЦ 112, манит, МКЦ бурст и натрий карбоксиметилкрахмал.

Наименьшее значение угла естественного откоса порошковых масс получали при использовании таблетозы, гарке плюс таб., кальция стеарата, натрий карбоксиметилкрахмала и кальция карбоната.

Наибольшее значение свободной насыпной плотности и насыпной плотности после усадки таблетируемых масс получали при использовании таблетозы, натрий карбоксиметилкрахмала, МКЦ + натрий КМЦ, гарке плюс таб., кальция карбоната, талька, МКЦ 302, МКЦ 12 и магния стеарата.

Процесс заполнения матрицы таблетной машины таблетируемой массой экстрактов травы козлятника, листьев черники и таурина лучше проходил при использовании натрий карбоксиметилкрахмала, маннита, кислоты стеариновой, МКЦ 200, магния карбоната основного.

ISSN 2312-0967. Pharmaceutical review. 2017. № 4 
Фармацевтична технологія, біофармація, гомеопатія

Pharmaceutical technology, biopharmacy, homeopathy

Наибольшее значение средней массы таблеток экстрактов травы козлятника, листьев черники и таурина получали при использовании кальция карбоната, натрий карбоксиметикрахмала, МКЦ 302, МКЦ + натрий КМЦ, магния стеарата и маннита.

Полученные результаты по показателям текучести порошковых масс, угла естественного откоса, свободной насыпной плотности после уплотнения указывают на возможность получения таблеток экстракта травы козлятника, экстракта листьев черники и таурина методом прямого прессования.

Выводы. Изучено влияние 25-ти ВВ на фрармако-технологические свойства таблетируемых масс (текучесть, угол естественного откоса, свободную насыпную плотность, насыпную массу после уплотнения, процесс засыпки таблетируемой массой матрицы таблеточной машины) и среднюю массу таблеток с экстрактом травы козлятника, экстрактом листьев черники и таурином. С помощью шестифракторного эксперимента - гипер-греко-латинского квадрата четвертого порядка изучено влияние 6-ти качественных фракторов на основные показатели таблетируемых масс с экстрактом травы козлятника, экстрактом листьев черники и таурином. Построены ранжированные ряды преимуществ влияния ВВ на 6 показателей порошковых масс и таблеток экстракта травы козлятника, экстракта листьев черники и таурина.

Ключевые слова: таблетки; фрармако-технологические показатели таблетируемых масс и таблеток; растительные экстракты; черника обыкновенная; козлятник лекарственный; сахарный диабет.

\title{
DEVELOPMENT OF OPTIMAL COMPOSITION AND TECHNOLOGY OF TABLETS BASED ON THE EXSTRACT OF GOAT'S RUE HERB, EXTRACT OF BILBERRY LEAVES AND TAURINE BY DIRECT COMPRESSION METHOD
}

\author{
O. Z. Barchuk ${ }^{1}$, T. A. Groshovyi², O. M. Zaliska ${ }^{1}$, V. Ja Shalata ${ }^{3}$, I. Yu. Revyatsky ${ }^{1}$ \\ Danylo Halytsky Lviv National Medical University ${ }^{1}$ \\ I. Horbachevsky Ternopil State Medical University² \\ Galychpharm PJSC ${ }^{3}$, Lviv \\ olvia2003@ukr.net
}

The aim of the work. Studying of the influence of excipients on the properties of the tablets mass and main indicators of the tablets in order to develop a new combined pill drug with hypoglycemic activity on the basis of dry extracts of the bilberry leaves, goat's rue herbs and taurine.

Materials and Methods. The main active substances are dry extracts of bilberry leaves and goat's rue herbs, taurine, excipients (fillers, sliding substances, weeders, lubricants). Investigation of the influence of excipients (E) on such parameters, as fluidity, the angle of natural deviation, free bulk mass, bulk mass after condensation, filling the tablet machine matrix with the powder mass, and the average weight of the tablets after pressing of the powder masses during formation of the tablets of goat's rue herb extract, extract of bilberry leaves and taurine by direct compression. The research was carried out in accordance with the requirements of the SPF 2 edition.

Results and Discussion. The influence of 25 excipients on the pharmaco-technological properties of powder masses (fluidity, the angle of natural deviation, free bulk mass, bulk mass after condensation, the process of filling the tablet machine matrix with the powder mass, the average weight of tablets) with the extract of the goat's rue herb, extract of bilberry leaves and taurine was studied. The effect of 6 qualitative factors on the basis of basic parameters of powder masses with extract of goat's rue herb, extract of bilberry leaves and taurine was studied with the help of six-factor experiment - hyper-Greco-Latin square. According to the totality of the studied basic indicators, the best combinations of excipients were selected for further study in order to develop the optimal composition and technology of tablets of bilberry leaves extract, extract of goat's rue herb and taurine.

The obtained results on the characteristics of fluidity of powder masses, the angle of natural slope, the free bulk mass and the bulk mass after sealing indicate the possibility of obtaining the tablets of the extract of goat's rue herb, the extract of bilberry leaves and taurine by direct compression method.

Conclusions. The influence of 25 excipients formed in 6 technological groups at 5 levels was studied. The effect of new excipients that appeared on the pharmaceutical market and were used to create and produce tablets by direct compression was studied for the first time. The excipients which showed the best results of the studied parameters were selected for the further study.

Key words: tablets; pharmaco-technological indexes of the tablets mass and tablets; plant extracts; bilberry; goat's rue; taurine; hypoglycemic.

ISSN 2312-0967. Фармацевтичний часопис. 2017. № 4 


\section{Список літератури}

1. Чекина Н. А. Сахарный диабет: возможности фрармакотерапии с использованием средств растительного происхождения / Н. А. Чекина, С. А. Чукаев, С. М. Николаев // Вестник Бурятского госуниверситета. - 2010. - № 12. - С. 71-78.

2. Интегративные подходы к научно обоснованной фритотерапии сахарного диабета и созданию специализированных пищевых продуктов для больных сахарным диабетом 2 типа / Т. Л. Киселева, В. А. Тутельян, А. А. Кочеткова [и др.] // Курский научно-практический вестник «Человек и его здоровье». - 2015. № 3. - C. 110-120.

3. Palit P. Novel weight-reducing activity of Galega officinalis in mice / P. Palit, B. L. Furman, A. I. Gray // J. Pharm. Pharmacol. - 1999. - Vol. 51. - P. 1313-1319.

4. Зворська О. 3. Чориця звичайна (Vaccinium myrtillus L.) - перспективна сировина для одержання лікарських засобів / О. 3. Барчук, Т. А. Грошовий // Фармацевтичний часопис - 2009. - № 3(9). - С. 29-33.

5. Огляд лікарських рослин, які виявляють гіпоглікемічну активність / Л. В. Вронська, Н. 3. Тимофтевич, М. А. Ежнед [та ін.] // Фармацевтичний часопис. - 2013. - № 2. - С. 142-148.

6. Актуальність розробки та створення антидіабетичних лікарських засобів на основі фітоекстракту козлятника лікарського (Galega officinalis L.) / О. 3. Барчук, Т. А. Грошовий, Г. Ю. Яцкова [та ін.] // Фітотерапія часопис. 2016. - 4. - С. 41-46.

7. Фитотерапия против диабета. Травы жизни / [ Корсун В. Ф., Корсун Е. В., Трумпе Т. Е. и др.]. - Москва : ЗАО «Издательство Центрполиграср», 2016. - С. 190.

8. Фітотерапія: навчальний посібник / [Андріюк Л. В., Гарник Т. П., Магулка І. В. та ін.]; за загальною редакцією д. мед. н., проф. Андріюка Л. В., д. мед. н., проф. Гарник Т. П. - Львів : Видавництво «Папуга», 2013. - С. 167.

\section{References}

1. Chekina, NA, Chukaev SA, Nikolaev SM. [Diabetes mellitus: possibilities of pharmacotherapy using plant remedies]. Vestnik Buryatskogo Gos Universiteta. 2010;12:71-8. Russian.

2. Kiseleva TL, Tutelyan VA, Kochetkova AA, Kiseleva MA. [Integrative approaches to science-based herbal therapy of diabetes and specialized foodstuffs development for patients with type 2 diabetes]. Kurskiy nauchno-prakticheskiy vestnik "Chelovek I ego zdorovya". 2015;3: 110-20. Russian.

3. Palit P, Furman BL, Gray Al. Novel weight-reducing activity of Galega officinalis in mice. J Pharm Pharmacol. 1999;51: 1313-9.

4. Zvorska OZ, Hroshovyi TA. [Vaccinium myrtillus as perspective raw materials for creating medicines]. Farmatsevt chasop. 2009;3(9): 29-33. Ukrainian.

5. Vronska LV, Tymoftevych NZ, Ezhned MA, Barchuk OZ. [Reviw of plant which exhibit hypoclycemic activity]. Farmatsevt chasop.2013;2: 142-8. Ukrainian.

6. Barchuk OZ, Kurylo Khl, Hroshovyi TA, Yatskova GYu. [Actuality of development and creation of antidiabetic drugs
9. Белей С. Я. Визначення оптимальних умов екстрагування та одержання сухого екстракту подорожника ланцетолистого / С. Я. Белей, Т. А. Грошовий // Фармацевтичний часопис. - 2015. - № 2. - C. 22-25.

10. Experimental study of goat's rue (Galega Officinalis L.) herb and its liquid extracts / O. Z. Barchuk, R. M. Lysiuk, A. I. Denys [et al.] // The Pharma Innovation Journal. - 2017. - Vol. 6 (11). - P 393-397.

11. Сучасний стан створення, виробництва та дослідження таблетованих лікарських препаратів / О. І. Онишків, Н. М. Белей, В. М. Коваль [та ін.] // Фармацевтичний часопис. - 2010. - № 3(15). - С.102-108.

12. Тригубчак О. В. Порівняльна технологічна оцінка нових допоміжних речовин при отриманні таблеток методом прямого пресування / О. В. Тригубчак, Т. А. Грошовий // Фармацевтична технологія. Історія розвитку та погляд в майбутнє. - 2008. - С. 278-283.

13. Державна Фармакопея України: в 3 т. / Державне підприємство «Український науковий фрармакопейний центр якості лікарських засобів». - 2-е вид. - Харків : Державне підприємство «Український науковий фрармакопейний центр якості лікарських засобів», 2015. - Т. 1. - 1128 с.

14. Дослідження гіпоглікемічних властивочтей сухого екстракту чорниці звичайної / Х. І. Курило, І. М. Кліщ, А. С. Вольська [та ін.] // Медична та клінічна хімія. 2016. - Т. 18, № 2. - С. 38-41.

15. Курило Х. І. Експериментальне визначення ефективної дози сухого екстракту козлятника лікарського та його гіпоглікемічних властивостей / Х. І. Курило, А. С. Вольська, І. М. Кліщ // Вісник проблем біології і медицини. - 2015. - Вип. 4. - Том 2 (125). - С 172-174. 16. Математичне планування експерименту при проведенні наукових досліджень в фрармації / [Т. А. Грошовий, В. П. Марценюк, Л. І. Кучеренко та ін.]. - Тернопіль : Укрмедкнига, 2008. - 367 с.

based on fitoextract of goa's rue (Galega officinalis L.)]. Fitoterapiia chosopys. 2016;4: 41-6. Ukrainian.

7. Korsun VF, Trumpe TE, Korsun EV, Ershov NV, Ogrenich NA. Phytotherapy against diabetes. Herbs of life. [Фитотерапия против диабета. Травы жизни] Moscow: ZAO Tsentrpoligraph Publishing House; 2016. Russian.

8. Andriyuk LV., Garnik TP. Phytotherapy. A manual for the general editorship of the doctor of medical sciences, professor Andriyuk LV, doctor of medical sciences, professor Garnik ТP. [Фітотерапія. Навчальний посібник за загальною редакцією д.мед.н., профресора Андріюка Л.В., д.мед.н., профресора Гарник Т.П.]. Lviv: Publishing House «Parrot»; 2013. Ukrainian.

9. Beley SYa, Hroshovyi TA. Definition of optimal extraction condition and obtaining of Plantain Lanceolata dru extract. Farmatsevt chasop. 2015;2: 22-5. Ukrainian.

10. Barchuk OZ, Lysiuk RM, Denys AI [Experimental study of goat's rue (Galega Officinalis L.) herb and its liquid extracts] The Pharma Innovation Journal. 2017;6(11): 393-7. Ukrainian.

11. Onishkiv OI, Beley NM, Koval VM. [Modern state of cre-

ISSN 2312-0967. Pharmaceutical review. 2017. № 4 
Фармацевтична технологія, біофармація, гомеопатія Pharmaceutical technology, biopharmacy, homeopathy

ation, production and research of tablet drugs]. Farmatsevt chasop.2010;3(15): 102-8. Ukrainian.

12. Trigubchak OV, Groshovoi TA. Comparative technological evaluation of new auxiliary substances in the preparation of tablets by direct compression. Pharmaceutical Technology. History of development and view into the future. 2008: 278-83. Ukrainian.

13. State Pharmacopoeia of Ukraine. [Державна Фармакопея України: в 3 т., 2-е вид.] Kharkiv: Derzhavne pidpryiemstvo «Naukovo-ekspertnyi farmakopeinyi tsentr»; 2015. Ukrainian.
14. Kurylo Khl, Klishch IM, Volska IM, Barchuk OZ. [Research of hypoglycemic properties of dry extract of Vaccinium myrtillus L.]. Medical and Clinical Chemistry. 2016;.2: 38-41. Ukrainian.

15. Kurylo Khl, Volska AS, Klishch IM. Study of the specific activity of goat's rue based hypoglycemic agent. Visnyk problem biolohii ta medytsyny. 2015;2(125): 172-4. Ukrainian.

16. Hroshovyi TA, Martsenyuk VP, Kucherenko LI, Vronska LV, Huryeyeva CM. Mathematical planning of experiment in pharmacy. [Математичне планування експерименту в орармаціiі] Ternopil: Ternopil State Medical University; 2008. Ukrainian.

Отримано 27.10.2017 